\title{
In-Vivo Models for Management of Pain
}

\author{
Naveed Muhammad \\ Department of Pharmacy, Abdul Wali Khan University, Mardan, Pakistan. \\ Email: drnaveedrph@gmail.com
}

Received November $17^{\text {th }}, 2013$; revised December $26^{\text {th }}$, 2013; accepted January $9^{\text {th }}, 2014$

Copyright (C) 2014 Naveed Muhammad. This is an open access article distributed under the Creative Commons Attribution License, which permits unrestricted use, distribution, and reproduction in any medium, provided the original work is properly cited. In accordance of the Creative Commons Attribution License all Copyrights (C) 2014 are reserved for SCIRP and the owner of the intellectual property Naveed Muhammad. All Copyright @ 2014 are guarded by law and by SCIRP as a guardian.

\begin{abstract}
Natural products are mostly considered safe, effective and with fewer side effects. For testing the natural products for their analgesic potential various in-vivo methods are used including chemical induced methods and thermal induced method. In the present review article we have discussed various in-vivo paradigms along with their merits and drawbacks. This mini review will help pharmacologist in performing various analgesic experiments.
\end{abstract}

\section{KEYWORDS}

\section{Natural Products; Analgesic Potential; Chemical Induced and Thermal Induced}

\section{Introduction}

Natural products are most widely used in the world for various ailments. Without doubt, medicinal plants are used for their therapeutic and health-enhancing properties. Natural remedies are used for both acute and chronic health problems. Man's health and well-being has been a subject of his primary concern from time immemorial. Centuries of observations, trials, error, and the innate sense of curiosity have equipped mankind with a great deal of knowledge and wisdom that it has today in the field of modern medicine. The knowledge of drugs goes back to prehistoric times as man has always continued to find remedies to his maladies through the material available in his environment. Sometimes this purpose was achieved through eating a particular animal flesh or through a ritual but mostly it was through the use of plants and herbs growing in his environment. Continuous observations on trial and error basis particularly regarding the use of herbs and plants for the treatment of ailments finally enabled man to establish various systems of medicine, for example, Sino medicine (China), Kampo medicine (Japan), Han medicine (Korea), Ayurvedic medicines.

To evaluate any substance (plant extract, isolated compound or synthetic compound) various in-vivo models are in practice. Different paradigms are used for test- ing central or peripheral or neuropathic pain.

\section{Models of Central Mechanisms}

\subsection{Hot Plate Test}

Material used: Animals (mice), hot plate and syringes. The most suitable animal model is mice with weight range 18 - 22 g. Keep in mind that as the weight of mice increased their sensitivity to noxious stimuli is decrease. The stopper of hot plate should be acute for measuring the latency time. The temperature regulation system of the hot plate should be checked properly before the start of experiment. In case of irregular control of temperature wrong results may be recorded. The syringes used for injection should be disposable and for single use only. The needle of syringe should be fast.

Procedure:

1) Weight the animals individually and acclimatize to laboratory conditions one hour before the start of experiment with water available ad libitum. Acclimatization of animals with laboratory conditions is necessary for accurate results. The withdrawal of food before the start of experiment is very essential because some foods substances have analgesic effect or may be the chemical composition of the food has synergistic effect with substance to be tested. 
2) Subject the animals to pre-testing on hot plate maintained at $55^{\circ} \mathrm{C} \pm 0.1^{\circ} \mathrm{C}$. Animals having latency time greater than 15 seconds on hot plate during pre-testing should be rejected. Only those animals should be selected for study which having latency time less than 6 seconds during pre-test.

3) All the animals should be divided in various groups each of at least six mice including negative control (normal saline, $10 \mathrm{ml} / \mathrm{kg}$, i.p), positive control (any analgesic drug with proper dose as given in Table 1) and treated group with the substance to be tested.

4) After $30 \mathrm{~min}$ of treatment the animals, place the animal on hot plate and record the latency time [time for which mouse remains on the hot plate $\left(55^{\circ} \mathrm{C} \pm 0.1^{\circ} \mathrm{C}\right)$ without licking or flicking of hind limb or jumping] in seconds. In order to prevent the tissue damage a cut-off time of 30 seconds would be imposed for all animals. The reading should be taken after $0,30,60,90$ and 120 min of administration of the test drug [1].

5) Percent analgesia can be calculated using the following formula:

$\%$ Analgesia $=($ Test latency - control latency $) /($ Cut off time - control latency) $\times 100$.

\subsection{Tail Immersion Test}

Material: hot water, animal holder, syringes.

Procedure:

1) Weight the animals individually and acclimatize to laboratory conditions one hour before the start of experiment with food and water available ad libitum.

2) Subject the animals to pre-testing by dipping the tail of animal in hot water maintained at $55^{\circ} \mathrm{C} \pm 0.1^{\circ} \mathrm{C}$. Animals having latency time greater than 15 seconds on hot plate during pre-testing should be rejected.

3) All the animals should be divided in various groups each of six mice including negative control (normal saline, $10 \mathrm{ml} / \mathrm{kg}$, i.p), positive control (any analgesic drug with proper dose as given in Table 1) and treated group with the substance to be tested.

Table 1. Some of the analgesic drugs used as positive control.

\begin{tabular}{cccc}
\hline S. No & Drug & Dose & References \\
\hline 1 & Diclofenac sodium & $10 \mathrm{mg} / \mathrm{kg}$ & {$[5]$} \\
2 & Paracetamol & $150 \mathrm{mg} / \mathrm{kg}$ & {$[5]$} \\
3 & Aspirin & $100 \mathrm{mg} / \mathrm{kg}$ & {$[6]$} \\
4 & Indomethacine & $10-40 \mathrm{mg} / \mathrm{kg}$ & {$[7]$} \\
5 & Ibuprofen & $150 \mathrm{mg} / \mathrm{kg}$ & {$[8]$} \\
6 & Morphine & $10 \mathrm{mg} / \mathrm{kg}$ & {$[6]$} \\
7 & Tramadol & $5 \mathrm{mg} / \mathrm{kg}$ & {$[5]$} \\
\hline
\end{tabular}

4) Keep the animal in vertical position to hang the tail, which was up to $5 \mathrm{~cm}$ into a pot of hot water maintained at $55^{\circ} \mathrm{C} \pm 0.5^{\circ} \mathrm{C}$. The time in seconds to withdraw the tail out of water was taken as the reaction time (Ta). The reading should be taken after $0,30,60,90$ and 120 min of administration of the test drugs. The cut-off time, i.e. time of no response was put at $30 \mathrm{~s}$, while $\mathrm{Tb}$ was consider the reaction time for control group [1].

Percentage analgesic activity $=\mathrm{Ta}-\mathrm{Tb} / \mathrm{Tb} \times 100$.

In these experiments the substance to be tested should be considered as analgesic if they increased the latency time in comparison with negative control animal. Failing to increase the latency time is considered as non analgesic agent. In order to find the involvement of opiodergic mechanism the analgesic effect can be antagonized with naloxon injection $(0.5 \mathrm{mg} / \mathrm{kg}$, s.c). For this purpose the animal should be treated with your test substance and then after 30 min of administration the same animals should be treated with naloxon subcutaneously. After 30 min of the naloxon injection test the animal for their analgesic effect using tail immersion or hot plat model. If the analgesic effect of diminished or entirely reduced then the substance should be considered as partial central analgesic or central analgesic agent respectively. The researchers are advised to test the negative control group and then positive control group. Following this order the researcher can easy jugged the effect of test substance. During experiment practice one animal at a time, this will reduce the work load and will be responsible for accurate results. The periodic checking of animal for the antinociceptive effect is in the favor of finding the onset of action and duration of action but this practice is also responsible for inflaming the paw of animals. Thermal nociception models such as hot plat and the tail immersion tests were used to evaluate central analgesic activity. The substance showing significant $(P<0.01)$ analgesic effect in both the hot plat and tail immersion tests, implicating both spinal and supraspinal analgesic pathways. In these pain paradigms $\operatorname{Tramadol}^{\mathrm{R}}$, which is similar to the action of opioid agonists (e.g. morphine), raised the pain threshold level within 30 min of administration. Both of these methods are simple and non expensive. The hot plat method is more reliable and scientific than that of tail immersion method. The control of temperature in tail immersion is more accurate and than in case of hot plate.

\section{Models of Peripheral Mechanisms}

\section{Acetic Acidinduced Writhing Test}

Materials: Acetic acid, animals specially mice, sample to be tested and normal saline for negative control.

Procedure: Acetic acid induced writhing test is one best, easy and simple chemical induced pain model. The following steps are recommended for this activity. 
1) All the animals selected for this experiment should be weighed individually. The recommended weight is 18 to 22 because the animals in this weight range are more sensitive for induction of writhing as compared to higher weight. The animals should be healthy and motile.

2) All the animals should be divided in various groups each of six mice including negative control (normal saline, $10 \mathrm{ml} / \mathrm{kg}$, i.p), positive control (any analgesic drug with proper dose as given in Table 1) and treated group with the substance to be tested.

3) After 30 min of step 2 the animals should be treated intraperitonialy (i.p.) with acetic acid for induction of writhing. Various concentrations $(0.5 \%, 0.7 \%$ or $1 \%)$ of acetic acid is recommended. After 5 min of acetic acid injection, the number of abdominal constrictions (writhes) should be counted for $10 \mathrm{~min}$ or $20 \mathrm{~min}$. The i.p. injection of anything caused writhing due puncturing of peritoneal membrane and these writhing due to injection terminated within in 5 min of post administration, secondly the absorption of acetic acid take about 5 min. Normally the number of writhing in negative control group is within in the range of 60 to 75 . If the substances to be tested protect the induced writhing, that will be considered as analgesic and vice versa.

Table 2. Some of natural products having analgesic effect.

\begin{tabular}{|c|c|c|c|c|}
\hline S. No & Compound name & Plant & Method used & Reference \\
\hline 1 & 2-hydroxy-1,4-naphthaquinone & Lawsonia inermis L. & & [9] \\
\hline 2 & Taraxasteryl myristate & Scorzonera latifolia & AA and tail-flick tests & \\
\hline 3 & Taraxasteryl acetate & Scorzonera latifolia & AA and tail-flick tests & \\
\hline 4 & Chalcones & Myracrodruon urundeuva & AA and formalin & {$[10]$} \\
\hline 5 & Kirenol & Siegesbeckia orientalis & $F R M$ & {$[11]$} \\
\hline 6 & Oncocalyxone A & Auxemma oncocalyx Taub & $A A$ & [12] \\
\hline 7 & 7-hydroxymitragynine & Mitragyna speciosa & TF and HP & [13] \\
\hline 8 & Vanillic acid & Lithrea molleoides & $A A$ & [14] \\
\hline 9 & Shikimic acid & Lithrea molleoides & $A A$ & {$[14]$} \\
\hline 10 & Urs stigmast-4 & Bryophyllum pinnatum & $A A$ & {$[15]$} \\
\hline 11 & 20 (21), 23-trien-3-one & Bryophyllum pinnatum & $A A$ & [15] \\
\hline 12 & $\begin{array}{l}\text { 6-hydroxy-4-(4-hydroxy-3-methoxy-phenyl)-3- } \\
\text { hydroxymethyl-7-methoxy-3, 4-dihydro-2-naphthaldehyde }\end{array}$ & Vitex negundo & $A A$ and $F R M$ & {$[16]$} \\
\hline 13 & Vitedoamine A & Vitex negundo & $A A$ and $F R M$ & {$[16]$} \\
\hline 14 & $\alpha$-mangostin & Garcinia mangostana & AA and HP & {$[17]$} \\
\hline 15 & $\gamma$-mangostin & Garcinia mangostana & $\mathrm{AA}$ and $\mathrm{HP}$ & {$[17]$} \\
\hline 16 & 11-O-galloylbergenin & Mallotus philippinensis & FRM & {$[18]$} \\
\hline 17 & Violacein & Chromobacterium violaceum & AA, FRM and HP & {$[19]$} \\
\hline 18 & Cyclobalanone & Scaphyglottis livida & HP & {$[20]$} \\
\hline 19 & $5 \alpha$-lanosta-24,24-dimethyl-9(11),25-dien-3 $\beta$-ol & Scaphyglottis livida & HP & {$[20]$} \\
\hline 20 & Gigantol & Scaphyglottis livida & HP & {$[20]$} \\
\hline 21 & 3,4'-dihydroxy-3',4,5-trimethoxybibenzyl & Scaphyglottis livida & HP & {$[20]$} \\
\hline 22 & Hofmeisterin III & Hofmeisteria schaffneri & AA and HP & {$[21]$} \\
\hline 23 & Marrubiin & Marrubium vulgare & AA & {$[22]$} \\
\hline 24 & (1 $\rightarrow$ 3)-linked $\beta$-D-glucopyranosyl & Pleurotus pulmonarius & FRM & {$[23]$} \\
\hline 25 & Stigmasterol & P. corcovadensis & AA, FRM, TF and HP & {$[24]$} \\
\hline 26 & Stigmasterol acetate & P. corcovadensis & AA, FRM, TF and HP & {$[24]$} \\
\hline 27 & $\beta$-sitosterol & P. corcovadensis & AA, FRM, TF and HP & {$[24]$} \\
\hline 28 & Vitexin & Urtica circularis & AA, FRM and HP & {$[25]$} \\
\hline 29 & Chlorogenic acid & Urtica circularis & AA, FRM and HP & {$[25]$} \\
\hline 30 & Caffeic acid and & Urtica circularis & AA, FRM and HP & {$[25]$} \\
\hline 31 & Vicenin-2 (6,8-di-C-glucosyl apigenin) & Urtica circularis & AA, FRM and HP & [25] \\
\hline
\end{tabular}

AA: acetic acid, FRM: Formaline, HP: hot plate, TF: tail flicking. 
The percent analgesia should calculate using formula:

Percent analgesia $=100-$ [No. of writhing in tested animals/No. of writhing in control animals] $\times 100$.

Acetic acid-induced writhing is a well recommended protocol in evaluating medicinal agents for their analgesic property. The pain induction caused by liberating endogenous substances as well as some other pain mediators such as arachidonic acid via cyclooxygenase, and prostaglandin biosynthesis [2,3]. This pain paradigm is widely used for the assessment of peripheral analgesic activity due to its sensitivity and response to the compounds at a dose which is not effective in other methods. The local peritoneal receptor could be the cause of abdominal writhing [4]. Pain sensation in acetic acid induced writhing paradigm is elicited by producing localized inflammatory response due to release of free arachidonic acid from tissue phospholipids via cyclo-oxygenase (COX), and producing prostaglandin specifically PGE2 and PGF2 $\alpha$, the level of lipoxygenase products may also increases in peritoneal fluids [2,3]. These prostaglandin and lipoxygenase products cause inflammation and pain by increasing capillary permeability. The substance inhibiting the writhing will have analgesic effect preferably by inhibition of prostaglandin synthesis, a peripheral mechanism of pain inhibition [3]. Table 2 presents various chemical compounds tested on different animal models.

To confirm the peripheral analgesic effect arachidonic acid, PGE2 or PGF2 $\alpha$ should be administering after 30 min of the administration of sample to be tested. If the analgesic effect is antagonized it means that the sample is prostaglandin inhibitor otherwise the analgesic effect may be due to some other mechanism.

\section{Conclusion}

Evaluation of substances to be tested is preliminary subjected for acetic acid induced writhing test and then thermal induced pain models which are used for peripheral and central analgesic potential. The correlation of these models is that if a chemical agent proved analgesic in model pain models would be considered as a useful analgesic agent.

\section{REFERENCES}

[1] N. Muhammad, N. ur Rehman, H. Khan, M. Saeed, A.-H. Gilani and E. Mekelle, "Prokinetic and Laxative Effects of the Crude Methanolic Extract of Viola Betonicifolia Whole Plant in Rodents," BMC Complementary and Alternative Medicine, Vol. 13, No. 1, 2013, p. 70. http://dx.doi.org/10.1186/1472-6882-13-70

[2] H. Khan, M. Saeed, A. U. H. Gilani, M. A. Khan, A. Dar and I. Khan, "The Antinociceptive Activity of Polygonatum Verticillatum Rhizomes in Pain Models,” Journal of Ethnopharmacology, Vol. 127, No. 2, 2010, pp. 521-527.

\section{http://dx.doi.org/10.1016/j.jep.2009.10.003}

[3] I. Duarte, M. Nakamura and S. Ferreira, "Participation of the Sympathetic System in Acetic Acid-Induced Writhing in Mice," Brazilian Journal of Medical and Biological Research, Vol. 21, No. 2, 1988, p. 341.

[4] M. Mbiantcha, A. Kamanyi, R. Teponno, A. Tapondjou, P. Watcho and T. Nguelefack, "Analgesic and Anti-Inflammatory Properties of Extracts from the Bulbils of Dioscorea bulbifera L. var Sativa (Dioscoreaceae) in Mice and Rats," Evidence-Based Complementary and Alternative Medicine: eCAM, Vol. 2011, 2011.

[5] N. Muhammad, M. Saeed and H. Khan, "Antipyretic, Analgesic and Anti-Inflammatory Activity of Viola Betonicifolia Whole Plant,” BMC Complementary and Alternative Medicine, Vol. 12, No. 1, 2012, p. 59.

http://dx.doi.org/10.1186/1472-6882-12-59

[6] H. Khan, M. Saeed, A.-U.-H. Gilani, M. A. Khan, A. Dar and I. Khan, "The Antinociceptive Activity of Polygonatum verticillatum Rhizomes in Pain Models," Journal of Ethnopharmacology, Vol. 127, No. 2, 2010, pp. 521-527. http://dx.doi.org/10.1016/j.jep.2009.10.003

[7] E. Franzotti, C. Santos, H. Rodrigues, R. Mourao, M. Andrade and A. Antoniolli, "Anti-Inflammatory, Analgesic Activity and Acute Toxicity of Sida cordifolia L. (Malva-Branca),” Journal of Ethnopharmacology, Vol. 72, No. 1, 2000, pp. 273-277.

http://dx.doi.org/10.1016/S0378-8741(00)00205-1

[8] M. Ibrar, N. Muhammad, H. K. Barkatullah, F. Jahan and N. Ashraf, "Antinociceptive and Anticonvulsant Activities of Essential Oils of Zanthoxylum Armatum," Phytopharmacol, Vol. 3, No. 1, 2012, pp. 191-198.

[9] B. Alia, A. Bashir and M. Tanira, "Anti-Inflammatory, Antipyretic, and Analgesic Effects of Lawsonia inermis L. (Henna) in Rats,” Pharmacology, Vol. 51, No. 6, 2008, pp. 356-363. http://dx.doi.org/10.1159/000139347

[10] G. Viana, M. Bandeira and F. Matos, “Analgesic and Antiinflammatory Effects of Chalcones Isolated from $M y$ racrodruon urundeuva Allemão," Phytomedicine, Vol. 10, No. 2, 2003, pp. 189-195.

http://dx.doi.org/10.1078/094471103321659924

[11] J.-P. Wang, Y.-M. Zhou, Y.-J. Ye, et al., “Topical AntiInflammatory and Analgesic Activity of Kirenol Isolated from Siegesbeckia orientalis," Journal of Ethnopharmacology, Vol. 137, No. 3, 2011, pp. 1089-1094. http://dx.doi.org/10.1016/j.jep.2011.07.016

[12] M. Ferreira, O. D. Nunes, J. B. Fontenele, O. D. Pessoa, T. L. Lemos and G. S. Viana, "Analgesic and Anti-Inflammatory Activities of a Fraction Rich in Oncocalyxone A Isolated from Auxemma oncocalyx," Phytomedicine, Vol. 11, No. 4, 2004, pp. 315-322.

http://dx.doi.org/10.1078/0944711041495227

[13] K. Matsumoto, S. Horie, H. Ishikawa, et al., “Antinociceptive Effect of 7-Hydroxymitragynine in Mice: Discovery of an Orally Active Opioid Analgesic from the Thai Medicinal Herb Mitragyna speciosa,” Life Sciences, Vol. 74, No. 17, 2004, pp. 2143-2156. http://dx.doi.org/10.1016/j.lfs.2003.09.054

[14] F. Morucci, P. Lopez, J. Miño, G. Ferraro and S. Gorzalczany, "Antinociceptive Activity of Aqueous Extract 
and Isolated Compounds of Lithrea molleoides,” Journal of Ethnopharmacology, Vol. 142, No. 2, 2012, pp. 401406. http://dx.doi.org/10.1016/j.jep.2012.05.009

[15] M. Afzal, G. Gupta, M. Rahman, et al., "Anti-Inflammatory and Analgesic Potential of a Novel Steroidal Derivative from Bryophyllum pinnatum," Fitoterapia, Vol. 83, No. 5, 2012, pp. 853-858. http://dx.doi.org/10.1016/j.fitote.2012.03.013

[16] C.-J. Zheng, W.-Z. Tang, B.-K. Huang, et al., "Bioactivity-Guided Fractionation for Analgesic Properties and Constituents of Vitex negundo L. Seeds,” Phytomedicine, Vol. 16, No. 6, 2009, pp. 560-567. http://dx.doi.org/10.1016/j.phymed.2008.12.001

[17] J. Cui, W. Hu, Z. Cai, et al., "New Medicinal Properties of Mangostins: Analgesic Activity and Pharmacological Characterization of Active Ingredients from the Fruit Hull of Garcinia mangostana L.,” Pharmacology Biochemistry and Behavior, Vol. 95, No. 2, 2010, pp. 166-172. http://dx.doi.org/10.1016/j.pbb.2009.12.021

[18] M. Arfan, H. Amin, N. Khan, I. Khan, M. Saeed and M. A. Khan, "Analgesic and Anti-Inflammatory Activities of 11-O-Galloylbergenin,” Journal of Ethnopharmacology, Vol. 131, No. 2, 2010, pp. 502-504. http://dx.doi.org/10.1016/j.jep.2010.06.040

[19] P. Antonisamy and S. Ignacimuthu, "Immunomodulatory, Analgesic and Antipyretic Effects of Violacein Isolated from Chromobacterium violaceum," Phytomedicine, Vol. 17, No. 3, 2010, pp. 300-304. http://dx.doi.org/10.1016/j.phymed.2009.05.018

[20] M. Déciga-Campos, J. F. Palacios-Espinosa, A. ReyesRamírez and R. Mata, “Antinociceptive and Anti-Inflam- matory Effects of Compounds Isolated from Scaphyglottis livida and Maxillaria densa," Journal of Ethnopharmacology, Vol. 114, No. 2, 2007, pp. 161-168. http://dx.doi.org/10.1016/j.jep.2007.07.021

[21] G. Angeles-López, A. Pérez-Vásquez, F. Hernández-Luis, et al., "Antinociceptive Effect of Extracts and Compounds from Hofmeisteria schaffneri," Journal of Ethnopharmacology, Vol. 131, No. 2, 2010, pp. 425-432. http://dx.doi.org/10.1016/j.jep.2010.07.009

[22] C. Meyre-Silva, R. Yunes, V. Schlemper, F. CamposBuzzi and V. Cechinel-Filho, "Analgesic Potential of Marrubiin Derivatives, a Bioactive Diterpene Present in Marrubium vulgare (Lamiaceae)," Il Farmaco, Vol. 60, No. 4, 2005, pp. 321-326. http://dx.doi.org/10.1016/j.farmac.2005.01.003

[23] F. R. Smiderle, L. M. Olsen, E. R. Carbonero, et al., “Anti-Inflammatory and Analgesic Properties in a Rodent Model of a $(1 \rightarrow 3),(1 \rightarrow 6)$-Linked $\beta$-Glucan Isolated from Pleurotus pulmonarius," European Journal of Pharmacology, Vol. 597, No. 1, 2008, pp. 86-91. http://dx.doi.org/10.1016/j.ejphar.2008.08.028

[24] Y.-F. Chen, H.-Y. Tsai and T.-S. Wu, “Anti-Inflammatory and Analgesic Activities from Roots of Angelica pubescens,” Planta Medica, Vol. 61, No. 1, 2007, pp. 2-8. http://dx.doi.org/10.1055/s-2006-957987

[25] S. Gorzalczany, C. Marrassini, J. Miño, C. Acevedo and G. Ferraro, "Antinociceptive Activity of Ethanolic Extract and Isolated Compounds of Urtica circularis," Journal of Ethnopharmacology, Vol. 134, No. 3, 2011, pp. 733-738. http://dx.doi.org/10.1016/j.jep.2011.01.025 